\title{
Developing E-Module for Prospective Sociology Educators: Constructing Multiple Choice Questions Based on Higher Order Thinking Skill (HOTS)
}

\author{
https://doi.org/10.3991/ijet.v16i07.21197 \\ Seli Septiana Pratiwi, Joan Hesti Gita Purwasih, \\ Desy Santi Rozakiyah, Deny Wahyu Apriyadi \\ Universitas Negeri Malang, Malang, Indonesia \\ Indah Wahyu Puji Utami $\left({ }^{\square}\right)$ \\ Nanyang Technological University, Nanyang Ave, Singapore \\ nie19.iwpude.ntu.edu.sg
}

\begin{abstract}
This research aims to develop e-modules that can be used by prospective educators in sociology subjects. This research was conducted based on an analysis of internal needs and external evaluation. Internal analysis was carried out by conducting surveys and FGDs on students to find indicators of their obstacles in mastering the material for making HOT questions. Meanwhile, the evaluation of external needs was carried out by finding deficiencies in the existing modules. Furthermore, e-module product development is carried out using the ADDIE model. The integration of audio-visual media in this e-module is a major advantage in product development. Users can understand the explanation of the module because the material explanation can be conveyed more specifically. The results of the evaluation show that the development of e-modules can help students more easily understand the material and practice developing HOT questions for sociology subjects. In addition, this module is also useful to teachers in several schools.
\end{abstract}

Keywords-E-module, HOTS, sociology, assessment

\section{Introduction}

The quality of education in all states is staked due to an inevitable global competition. Human resource is required to have adequate competency in all states. Unfortunately, Indonesia seems to be unprepared for the challenge. This condition can be seen from the fluctuating result of PISA (Program for International Student Assessment) evaluation. 
Table 1. Result of Indonesia's PISA

\begin{tabular}{|l|c|c|c|}
\hline \multirow{2}{*}{ Competency } & \multicolumn{3}{|c|}{ Mean Score of PISA (Years) } \\
\cline { 2 - 4 } & $\mathbf{2 0 1 2}$ & $\mathbf{2 0 1 5}$ & $\mathbf{2 0 1 8}$ \\
\hline Reading & 382.3 & 386 & 358 \\
\hline Mathematics & 375 & 386 & 379 \\
\hline Science & 382 & 403 & 396 \\
\hline
\end{tabular}

PISA is a part of program held by OECD (Organization for Economic Co-operation and Development). PISA's data of 2012, 2015, and 2018 show that Indonesia's score is still below the world's mean score [1], [2], [3]. The result of Indonesia's PISA in 2018 is lower than other South East Asian countries like Thailand, Brunei Darussalam, Malaysia, and Singapore (Figure 1).

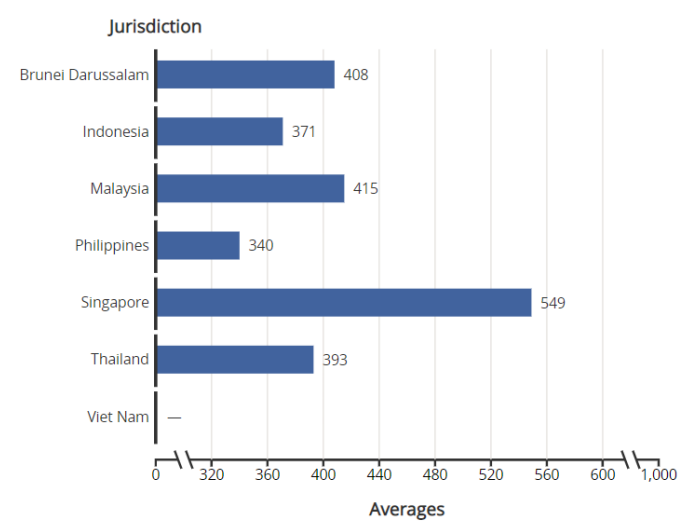

Fig. 1. Averages for PISA 2018 (reading, mathematics and science)

This international assessment should be considered as a reference to assess an education's success. The problems used in the test contain students' literacy and high order thinking skill (HOTS). These abilities are very important because with high order thinking skill the students can learn to be an individual who can solve problem productively [4]. Some states even change their curriculums because of unsatisfactory effect of PISA evaluation's outcome, such as Germany that changed its curriculum in 2000. Such condition is called 'PISA Shock'[5]. In addition, Australia also made curriculum reform due to their unsatisfactory PISA outcome [6].

Indonesian government also responds stringently to the PISA outcome. Such condition can be seen from the direction of Indonesian education policy building on PISA outcome in recent years [7]. Evidently, in the policy of changing curriculum 2006 into 2013, PISA outcome becomes one of premises taken into account. This condition can be observed from the introduction section of external factor into the Ministry of Education's policy such as PERMENDIKBUD No. 69 of 2016 [8]. Around the end of 2019 Minister of Education and Culture made a breakthrough in education policy by raising a theme "Merdeka Belajar (Freedom to Learn)". It highlights, among others, the policy 
of replacing national examination with minimum competency assessment model consisting of literacy, numerical skill, and noble character [9]. The assessment is made to match the quality of problems in PISA.

The change of curriculum is not the only way of improving the quality of education, but teacher competency reinforcement should also be done. It is well established that teacher plays an important role in developing human resource quality. Therefore, teacher is required to be able to develop their competency sustainably. Unfortunately, the demand has not been satisfactory fulfilled by teachers in Indonesia. Work overload, access, welfare, experience, and age are the constraints often encountered [10]. Nevertheless, the reinforcement of teacher competency should remain to be done by providing credible and adequate information source facilities. These problems should also be addressed especially by the colleges or universities, particularly those organizing education field study program. The student-oriented learning such as problem based learning generally can evidently improve the students' high order thinking skill [11].

Departing from social reality aforementioned, an attempt is required to reinforce the prospective educators and teachers in order to develop their competency. In this research, the reinforcement of competency for prospective teachers of Sociology subject is conducted by facilitating the development of learning source in the form of E-module to develop HOT problems in multiple choice form. There has been a module previously containing the guideline of Sociology HOT problems in writing [4]. However, many shortages should be corrected. Therefore, we attempted to evaluate the current product and to revise it by developing a new and better product in form of e-module. Through e-module, students/prospective teachers of sociology subject can prepare themselves and learn independently to develop HOT problems. These abilities are very important to students in both short and long terms. In short term, the students are expected to develop HOT problem to equip them in doing apprenticeship in educational institution. Meanwhile, in long term, this module is expected to reinforce the capability in facing work realm as educators. E-module is also accessible to the public, so that teachers can utilize it as well.

\section{Method}

This research and development used ADDIE (Analysis, Design, Develop, Implementation, and Evaluation). This research process developed design from ADDIE model initiated by Brach [12]. The implementation of model application is presented briefly in table 2 . 
Table 2. ADDIE research design

\begin{tabular}{|c|c|c|c|c|}
\hline \multicolumn{5}{|c|}{ Concept } \\
\hline Analyze & Design & Develop & Implement & Evaluate \\
\hline $\begin{array}{l}\text { Identifying the weak- } \\
\text { nesses of product }\end{array}$ & $\begin{array}{l}\text { Formulating devel- } \\
\text { opment step }\end{array}$ & $\begin{array}{l}\text { Developing and } \\
\text { validating the } \\
\text { product }\end{array}$ & $\begin{array}{l}\text { Disseminating } \\
\text { product to users }\end{array}$ & $\begin{array}{l}\text { Measuring the } \\
\text { quality of product }\end{array}$ \\
\hline \multicolumn{5}{|c|}{ General Procedure } \\
\hline $\begin{array}{l}\text { (1) Doing Focus Group } \\
\text { Discussion (FGD) and } \\
\text { survey on students' com- } \\
\text { prehension. } \\
\text { (2) Analyzing the preex- } \\
\text { isting module by involv- } \\
\text { ing related stakeholders. } \\
\text { (3) Mapping the weak- } \\
\text { nesses existing to formu- } \\
\text { late recommendation by } \\
\text { involving alumni. }\end{array}$ & $\begin{array}{l}\text { (1) Accommodating } \\
\text { the weaknesses by } \\
\text { developing frame- } \\
\text { work/pattern. } \\
\text { (2) Examining the } \\
\text { feasibility of design. } \\
\text { (3) Revising the de- } \\
\text { sign. }\end{array}$ & $\begin{array}{l}\text { (1) Developing } \\
\text { prototype module. } \\
\text { (2) Analyzing the } \\
\text { feasibility of prod- } \\
\text { uct internally. } \\
\text { (3) Improving the } \\
\text { product. }\end{array}$ & $\begin{array}{l}\text { (1) Socializing the } \\
\text { product/ asking for } \\
\text { final input. }\end{array}$ & $\begin{array}{l}\text { Comparing new } \\
\text { and old products } \\
\text { and assessing the } \\
\text { final feasibility. }\end{array}$ \\
\hline
\end{tabular}

\section{$3 \quad$ Result and Discussion}

The result of research is presented by showing each of development model stages that has been implemented.

\subsection{Result of need analysis and evaluation on previous product}

The analysis of users' (students') need was conducted in FGD. Furthermore, the output of FGD was abstracted into indicators to prepare questionnaires to screen the opinion of other 32 students. The result of data processing is shown in table 3 .

Table 3. Constraints faced by the students in developing problems

\begin{tabular}{|c|l|l|}
\hline No. & \multicolumn{1}{|c|}{ Output of FGD } & \multicolumn{1}{|c|}{ Output of Questionnaire } \\
\hline 1. & It is difficult to prepare stimulus and problem sentence well & $28.1 \%$ very agree and 50\% agree \\
\hline 2. & $\begin{array}{l}\text { Not mastering Sociology material for Senior High School } \\
\text { level }\end{array}$ & $6.4 \%$ very agree and $43.8 \%$ agree \\
\hline 3. & $\begin{array}{l}\text { Mastering poorly the implementation of Bloom's taxon- } \\
\text { omy (revised by Anderson). }\end{array}$ & $\begin{array}{l}15.6 \% \text { very agree and } 68.8 \% \\
\text { agree }\end{array}$ \\
\hline 4. & Learning duration needed is inadequate & $40 \%$ very agree and 30\% agree \\
\hline 5. & Lecturer has poor explaining ability & $6.3 \%$ very agree and $25 \%$ agree \\
\hline
\end{tabular}

In addition to students' opinion, need analysis is also conducted by analyzing the weakness of preexisting product. Module of Sociology HOT problems development has been published previously by government through Directorate General of Senior 
High School in 2019. Nevertheless, considering the result of expert analysis (representation of teachers and lecturers) the module still has some weaknesses as presented in Table 4.

Table 4. Students' constraint in preparing problems

\begin{tabular}{|c|l|l|}
\hline No. & \multicolumn{1}{|c|}{ Aspect } & \multicolumn{1}{|c|}{ Finding } \\
\hline 1. & Media & Still in simple PDF form \\
\hline 2. & $\begin{array}{l}\text { Essential material of } \\
\text { Sociology }\end{array}$ & Many materials are still unsolved with Basic Competency of 2013 Curriculum \\
\hline 3. & Example problem & $\begin{array}{l}\text { Some problem examples are still found incompatible to Bloom's taxonomy } \\
\text { level revised by Anderson. }\end{array}$ \\
\hline
\end{tabular}

Subsequently, we asked for the alumni's opinion, who are work as teachers in some schools, through another round of FGD. Their opinions are explored to find out the criteria of good e-module as the material of product development in this study. As a result, the following recommendations were obtained: 1) module should contain chronological and clear instruction of problems organization, 2) module should increase the composition of way of preparing problems stimulus variety, 3) module should contain more HOT-problems implementation, and 4) module should use language understandable to the users.

\subsection{Design of E-Module product}

Considering the result of need analysis elaborated, we prepared the product development design with the following specifications: 1) E-pub-based, 2) containing audiovisual media in the form of tutorial video, 3) open access, 4) focusing on HOT problems study for Sociology subject of Senior High School for the 2013 curriculum. The product development design is presented in table 5.

Table 5. Design of E-Module product content

\begin{tabular}{|l|l|}
\hline \multicolumn{1}{|c|}{ Basic Elements } & \multicolumn{1}{|c|}{ Sub Content } \\
\hline Introduction & $\begin{array}{l}\text { Description of module content } \\
\text { Prequisite } \\
\text { Module Using Instruction } \\
\text { Objective } \\
\text { Competency } \\
\text { Pretest }\end{array}$ \\
\hline Essential Material of Sociology & Objective \\
\hline Higher Order Thinking (HOT) & Material Elaboration \\
\hline Multiple Choice problem & \\
\hline Sociology HOT Problem Application & $\begin{array}{l}\text { Summary } \\
\text { Evaluation }\end{array}$ \\
\hline Conclusion & \\
\hline
\end{tabular}




\subsection{E-Module product development}

Having formulated the content, the author developed product and presented it in the form of prototype. The example output of prototype product development is shown in Figure 2.

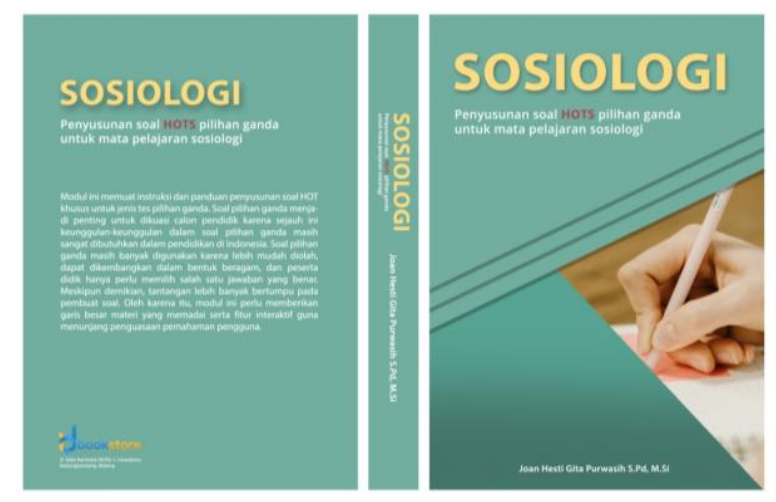

Fig. 2. Prototype product of E-Module

\subsection{Implementation and evaluation of e-module product}

The product organized was trialed accordingly and assessed by validators with regards to the language, media, and material. Some indicators of product feasibility were formulated. Each of assessment aspects contains ten indicators. Then, the experts conducted assessment by filling in the score to the options available. The categorization of point for each product is: very good (score 4), good (score 3), bad (2) and very bad (1). From the result, the following conclusions can be drawn.

Table 6. Result of Validation

\begin{tabular}{|l|l|l|}
\hline \multicolumn{3}{|c|}{ Assessment Aspects } \\
\hline \multicolumn{1}{|c|}{ Media } & \multicolumn{1}{|c|}{ Language } & \multicolumn{1}{c|}{ Content } \\
\hline $\begin{array}{l}\text { Total Score: } 30 \\
\text { Conclusion: good }\end{array}$ & $\begin{array}{l}\text { Total Score: } 30 \\
\text { Conclusion: good }\end{array}$ & $\begin{array}{l}\text { Total Score: } 32 \\
\text { Conclusion: very good }\end{array}$ \\
\hline
\end{tabular}

The result of validation process indicates that the product developed is feasible and in accordance with the field need. Thus, the product can be utilized in teaching as the supplement to learning source.

\section{Conclusion}

Preparing multiple choice problems with HOT level cannot be mastered completely by students in teaching process solely. Therefore, the lecturers should actively explore data and organize the strategy to solve the problems. Through this media development, 
the students can learn independently and develop HOT problems more easily. In addition, lecturers can also develop the quality of learning adaptively and their scholarship through learning innovation. Recalling the Covid-19 threat still affecting in 2021, the policy of school from home will likely last longer. Therefore, this kind of product development will be very desirable to students to study from home.

\section{$5 \quad$ References}

[1] OECD (2019), "Reading performance (PISA) (indicator)," 2019. https://data.oecd.org/pisa/ reading-performance-pisa.htm (accessed Dec. 24, 2019). https://doi.org/10.1787/ eco_surveys-che-2013-graph32-en

[2] OECD (2019), "Mathematics performance (PISA)," 2019. https://data.oecd.org/pisa /mathematics-performance-pisa.htm\#indicator-chart (accessed Dec. 24, 2019). https://doi.org/10.1787/factbook-2014-table169-en

[3] OECD (2019), "Science performance (PISA)," 2019. https://data.oecd.org/pisa/science-performance-pisa.htm\#indicator-chart (accessed Dec. 24, 2019). https://doi.org/10.1787/ f30da688-en

[4] R. R. Pratama and R. A. Pramesti, "The Importance of STIM-HOTS and Critical Thinking Skill in Disruption Era," Soc. Humanit. Educ. Stud. Conf. Ser., 2018. https://doi.org/10.20961/shes.v1i1.24304

[5] F. Waldow, "What PISA did and did not do: Germany after the 'PISA-shock,"” Eur. Educ. Res. J., 2009. https://doi.org/10.2304/eerj.2009.8.3.476

[6] K. Starr, "The influences and implications of PISA: An Australian perspective.," AASA J. Scholarsh. Pract., 2014.

[7] I. Pratiwi, "Efek Program PISA Terhadap Kurikulum di Indonesia," J. Pendidik. dan Kebud., 2019. https://doi.org/10.24832/jpnk.v4i1.1157

[8] Kemendikbud, Peraturan Menteri Pendidikan Pendidikan dan Kebudayaan Republik Indonesia Nomor 69 Tahun 2013 Tentang Kerangka Dasar dan Struktur Kurikulum Sekolah Menengah Atas/Madrasah Aliyah. Indonesia, 2013, pp. 1-256. https://doi.org/10. 31219/osf.io/gepqc

[9] Pengelola Web KEMDIKBUD, "Mendikbud Tetapkan Empat Pokok Kebijakan Pendidikan 'Merdeka Belajar,” SIARAN PERS Nomor: 408/sipres/A5.3/XII/2019, 2019. https://www.kemdikbud.go.id/main/blog/2019/12/mendikbud-tetapkan-empat-pokok-kebijakan-pendidikan-merdeka-belajar (accessed Dec. 26, 2019). https://doi.org/10.31219/ osf.io/67rcq

[10] M. I. Rahida Aini, A. Rozita, and A. Zakaria, "Can Teachers' Age and Experience influence Teacher Effectiveness in HOTS?” Int. J. Adv. Stud. Soc. Sci. Innov., 2018. https://doi. org/10.30690/ijassi.21.11

[11] Y. Suhirman and S. P. Agus Muliadi, "The Effect of Problem-Based Learning with Character Emphasis Toward Students' Higher-Order Thinking Skills and Characters,” Int. J. Emerg. Technol. Learn., vol. 15, no. 6, pp. 183-191, 2020. https://doi.org/10.3991/ ijet.v15i06.12061

[12] R. M. Branch, Instructional design: The ADDIE approach. USA: Springer, 2010 


\section{Authors}

Seli Septiana Pratiwi is a lecturer at Sociology Department, Faculty of Social Sciences, Universitas Negeri Malang. Email: seli.pratiwi.fis@um.ac.id.

Joan Hesti Gita Purwasih is a lecturer at Sociology Department, Faculty of Social Sciences, Universitas Negeri Malang. Email: joan.hesti.fis@um.ac.id.

Desy Santi Rozakiyah is a lecturer at Sociology Department, Faculty of Social Sciences, Universitas Negeri Malang. Email: desy.rozakiyah.fis@um.ac.id.

Deny Wahyu Apriyadi is a lecturer at Sociology Department, Faculty of Social Sciences, Universitas Negeri Malang. Email: deny.apriyadi.fis@um.ac.id.

Indah Wahyu Puji Utami is a lecturer at History Deptarment, Faculty of Social Sciences, Universitas Negeri Malang and a PhD student at Humanities and Social Studies Education, National Institute of Education, Nanyang Technological University. Email: nie19.iwpu@e.ntu.edu.sg.

Article submitted 2021-01-14. Resubmitted 2021-02-23. Final acceptance 2021-02-24. Final version published as submitted by the authors. 